\title{
Genomic and phenotypic attributes of novel salinivibrios from stromatolites, sediment and water from a high altitude lake
}

\author{
Marta F Gorriti ${ }^{1,2+}$, Graciela M Dias ${ }^{2+}$, Luciane A Chimetto ${ }^{2}$, Amaro E Trindade-Silva ${ }^{2,3}$, Bruno S Silva ${ }^{2}$, \\ Milene MA Mesquita², Gustavo B Gregoracci ${ }^{2}$, Maria E Farias ${ }^{1}$, Cristiane C Thompson ${ }^{2}$ \\ and Fabiano L Thompson ${ }^{2,4,5^{*}}$
}

\begin{abstract}
Background: Salinivibrios are moderately halophilic bacteria found in salted meats, brines and hypersaline environments. We obtained three novel conspecific Salinivibrio strains closely related to S. costicola, from Socompa Lake, a high altitude hypersaline Andean lake (approx. 3,570 meters above the sea level).

Results: The three novel Salinivibrio spp. were extremely resistant to arsenic (up to $200 \mathrm{mM} \mathrm{HAsO} 4^{2-}$ ), $\mathrm{NaCl}$ (up to $15 \%)$, and UV-B radiation ( $19 \mathrm{KJ} / \mathrm{m}^{2}$, corresponding to 240 minutes of exposure) by means of phenotypic tests. Our subsequent draft genome ionsequencing and RAST-based genome annotation revealed the presence of genes related to arsenic, $\mathrm{NaCl}$, and UV radiation resistance. The three novel Salinivibrio genomes also had the xanthorhodopsin gene cluster phylogenetically related to Marinobacter and Spiribacter. The genomic taxonomy analysis, including multilocus sequence analysis, average amino acid identity, and genome-to-genome distance revealed that the three novel strains belong to a new Salinivibrio species.

Conclusions: Arsenic resistance genes, genes involved in DNA repair, resistance to extreme environmental conditions and the possible light-based energy production, may represent important attributes of the novel salinivibrios, allowing these microbes to thrive in the Socompa Lake.
\end{abstract}

Keywords: Arsenic, Salinity, UV radiation, Xanthorhodopsin, Extreme environment

\section{Background}

Socompa is a high altitude Andean lake (HAAL) located at the base of the still active Socompa volcano, at the northwestern part of Argentina in the Puna region, at about 3,570 meters above the sea level (masl). This lake presents unique features such as high alkalinity, hypersalinity and extremely high arsenic concentration. Additionally, actively forming stromatolites inhabit the Socompa Lake [1]. Stromatolites are considered evidence of early life on Earth with geological records dating back to 3.5 billion years [2-4]. The term stromatolites has been raising

\footnotetext{
* Correspondence: fabiano.thompson@biologia.ufrj.br

${ }^{\dagger}$ Equal contributors

'Laboratório de Microbiologia, Instituto de Biologia, Universidade Federal do Rio de Janeiro (UFRJ), Rio de Janeiro, Brasil

${ }^{4}$ SAGE-COPPE, CT2 Rua Moniz de Aragão, no.360 - Bloco 2, Rio de Janeiro, Brasil

Full list of author information is available at the end of the article
}

discussions since its introduction by Kalkowsky in 1803, and therefore, in this work we will follow, in this work, the recently established concept that "stromatolites are macroscopically layered authigenic microbial sediments with or without interlayered abiogenic precipitates" [5]. Modern stromatolites have been recorded in only a few locations and, in general, at low to medium altitudes, with the exception of the Obsidian Pool in the Yellowstone National Park located about 2,400 masl [6-12].

The study of microbes associated with Socompa stromatolites and their environment could provide further understanding of the evolution under extremely harsh conditions. Vibrio costicola was first described by Smith in 1938 [13]. This species was then transferred to the new genus Salinivibrio [14], which today comprises four species [14-17]. The most recently described species is Salinivibrio sharmensis [17]. Salinivibrios are moderately 
halophilic bacteria distributed in salted meats, brines and hypersaline environments. They have developed cellular mechanisms to thrive in extremophilic conditions, such as hypersalinity $[18,19]$. Salinivibrio costicola has been used as a model organism for studies of osmoregulation and other physiological mechanisms [20,21]. However, little is known concerning the genomic and phenotypic repertoire of salinivibrios related to survival under high UV radiation, salinity and arsenic concentration. The study of salinivibrios from the Socompa Lake could provide us with a better understanding of the attributes of these bacteria and of possible aspects of genome evolution related to extreme environments.

In the course of the study of the microbial diversity of stromatolites at the Socompa Lake, a collection of salinivibrios was obtained (Figure 1). We then used Ion Torrent sequencing to evaluate the genomic repertoire of three novel representative strains related to life in an extreme environment. In addition, we evaluated the phenotypic attributes (UV and arsenic tolerance) of the three strains. Our aim was to determine the possible genomic and phenotypic attributes that allow the three novel Salinivibrio strains to inhabit the Socompa Lake.

\section{Results and discussion}

\section{General features of the three novel Salinivibrio strains}

Salinivibrio spp. S10B, S34 and S35 strains were isolated from stromatolite, sediment and water of Socompa Lake (S $24^{\circ} 35^{\prime} 34^{\prime \prime} \mathrm{W} 68^{\circ} 12^{\prime} 42^{\prime \prime}$ ) respectively, during February 2011 (Figure 1). The isolated strains presented rounded, entire edges and cream pinkish colonies. The cells are Gram-negative, motile, non-sporulating curved rods. The re-annotated genome of the Salinivibrio costicola subsp. costicola ATCC33508 and the genomes sequenced of the Salinivibrio spp. S10B, S34 and S35 covered total length of
4,781,671, 3,352,016, 3,332,225 and 3,406,510 bp, respectively. For the newly sequenced salinivibrios, estimated coverage depths of 13, 15 and 17 fold, and average GC contents of $49.5 \%, 49.4 \%$ and $49.5 \%$ were observed (see Additional file 1: Table S1). In the genome of the Salinivibrio spp. S10B, S34 and S35, the annotation by RAST identified 3,429, 3,979, 3,477 coding sequences (CDSs), respectively. On average, $29 \%$ of the CDS in the Salinivibrio strains were annotated as hypothetical proteins. We observed the presence of specific genes in each strain by pairwise reciprocal BLASTn analysis using strain S35 as reference (Figure 2). Strain S34 (isolated from sediment) showed 203 genes with no similarity to the other strains. The majority of these genes (89\%) were annotated as hypothetical proteins. The remaining genes were related to with osmotic stress, Clustered Regularly Interspaced Short Palindromic Repeats elements (CRISPR), CRISPRassociated (Cas) modules (Ramp module) and capsular polysaccharide synthesis enzyme that are involved to development of biofilms (see Additional file 2: Table S2). The biofilm formation may be a strategy for survival during periods of nutrient scarcity [22], protection against environmental changes [23], trapping and absorbing nutrients, resistance to antibiotics, and for the establishing of favorable interactions with other bacteria [24]. Also, the extracellular matrix substances produced by S34 (Figure 1) may be important as a site of mineral nucleation in the stromatolite [1]. The CRISPR-Cas modules, on the other hand, constitute adaptive immunity systems found in several prokaryotic communities and are associated with defense against the invasion of foreign genetic elements $[25,26]$.

Strain S35 (isolated from the water) presented 233 genes, which were not detected in the other strains. A total of $60 \%$ of these genes were annotated as hypothetical

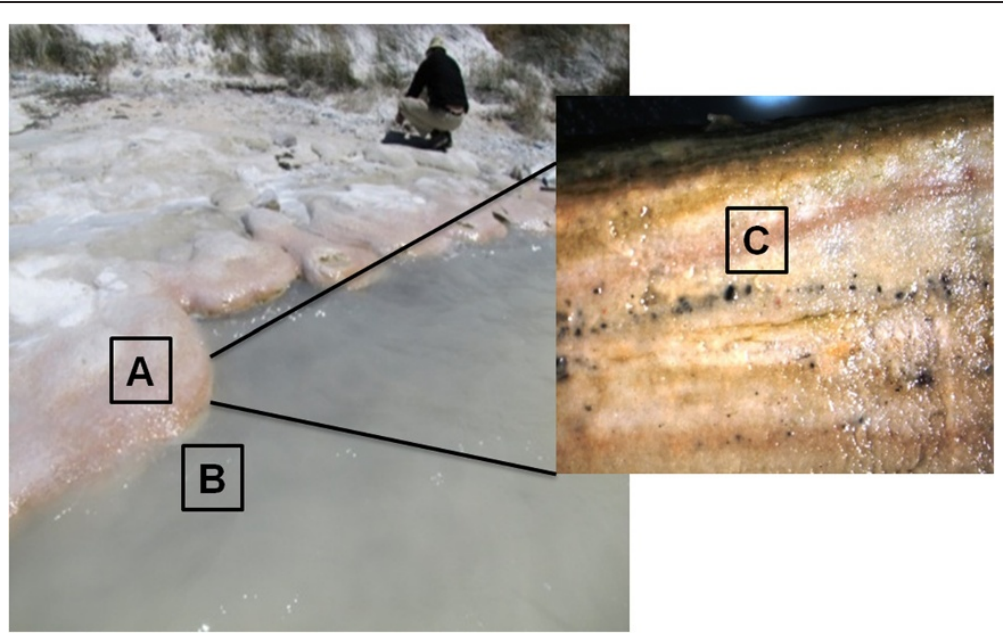

Figure 1 High altitude Socompa lake (3570 masl). Sampling sites from which the strains were isolated. Square A: sediment sample (Salinivibrio sp. S34); square B: water sample (Salinivibrio sp. S35); square C: pink layer sample from stromatolite (Salinivibrio sp. S10B). 


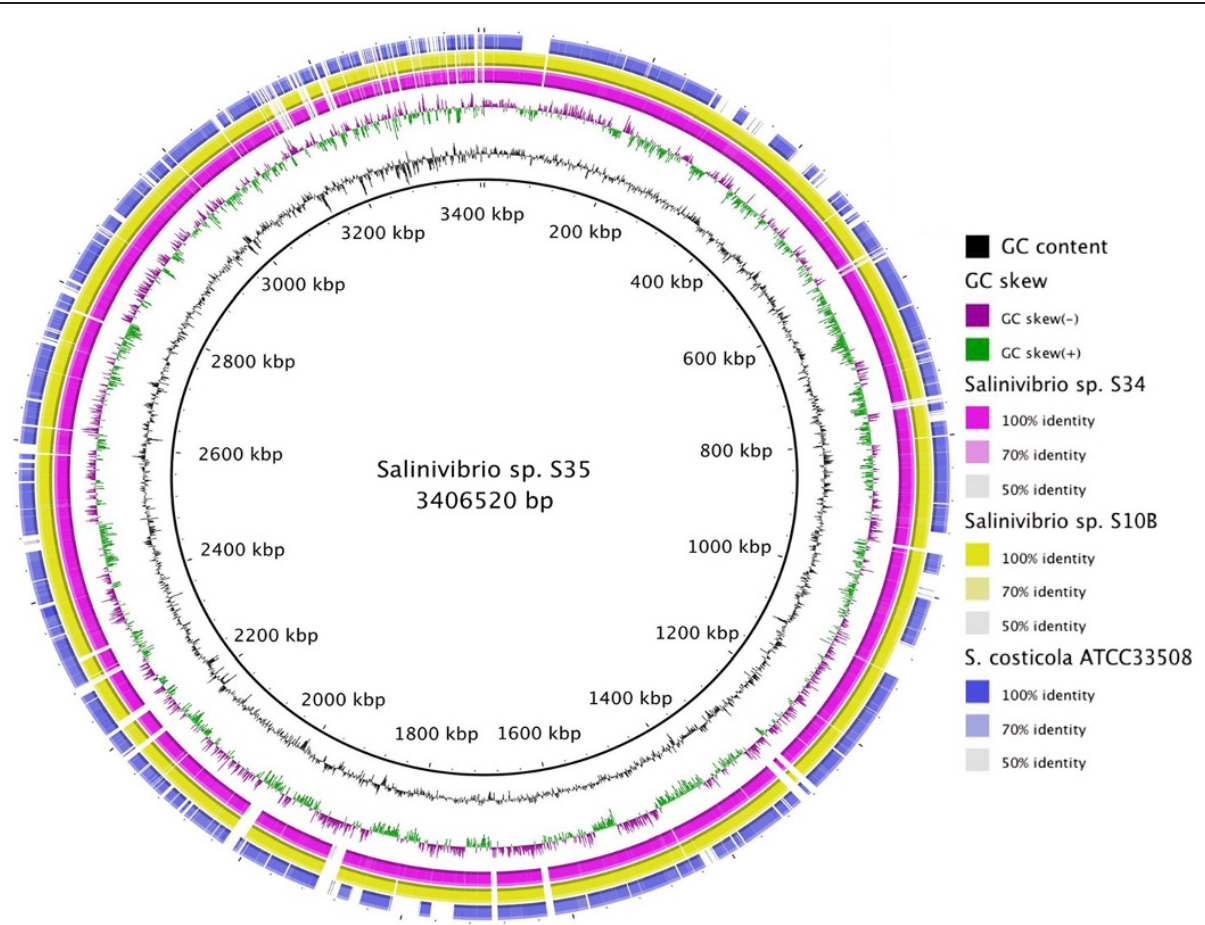

Figure 2 Comparison of Salinivibrio genomes. The figure shows blastn results using Salinivibrio sp. S35 as reference sequence against other Salinivibrio genomes (S34, S10B e ATCC33508).

proteins. The other genes were annotated into cobalamine biosynthesis, Tra elements and Type II/IV secretion systems among others (see Additional file 3: Table S3). Considering the water column origin, strain S35 could be positively interacting with dominant diatomite of Socompa Lake water (Navicula sp.) and stromatolites (Amphora sp.) through exudates of cobalamin, a vitamin which is necessary for the development of such microalgae communities $[1,27]$. Diatoms may, in turn, provide labile dissolved organic matter for the salinivibrios. This plausible ecological interaction suggests that further studies are needed in order to unravel the microbial ecology of the Socompa lake.

Finally, Salinivibrio sp. S10B (isolated from stromatolite) revealed 134 exclusive genes when compared with the other sequenced strains. Besides hypothetical genes (83\%), this pool also contained several ORFs with similarity to phage genes (see Additional file 4: Table S4). The majority of phage related genes are flanked by IS elements, tRNAs, and integrases genes, indicating an important role of horizontal genetic transfer in genome evolution in the Socompa lake. The specific genomic content of each Salinivibrio strain could be related with unique metabolic properties of these strains in response to their distinct ecological niches. To this end, efforts toward the characterization of the majority of the strainsspecific genes with unknown function (hypothetical proteins) will be critical.

\section{Taxonomic assignment}

Phylogenetic analyses based on 16S rRNA gene sequences (1,561 bp) and Multilocus Sequence Analysis (MLSA) classified the three novel strains S10B, S34 and S35 in a tight monophyletic group in the genus Salinivibrio (Figure 3; see Additional file 5: Figure S1). Strains S10B, S34 and S35 showed more than 99.4\% mutual 16S rRNA and multilocus sequence similarity (ie. ftsZ, rpoA, recA, topA, gapA, mreB, gyrB and pyrH; ca. 10,735 nt). They were most closely related to the $S$. costicola species, presenting between 99.1 and 99.2\% 16S rRNA gene sequence similarity with S. costicola subsp. alcaliphilus $18 \mathrm{G}^{\mathrm{T}}$ and between 98.6 and $98.7 \%$ 16S rRNA gene sequence similarity with and S. costicola subsp. costicola ATCC33508. However, a closer taxonomic examination of the genomes indicated that the three novel strains had only 93\% Amino Acid Identity (AAI) and $<70 \%$ in silico Genome-toGenome Hybridization similarity (GGDH) with the type strain of S. costicola subsp. costicola (ATCC33508). These values are below the thresholds for species characterization [28]. We suggest that the novel strains (S10B, S34 and S35) may belong to a new species of the Salinivibrio genus, for which we propose the name Salinivibrio socompensis (type strain LIMLA S10B $=$ BNM 537). The three novel strains can also be distinguished from the closest taxon S. costicola subsp. alcaliphilus by means of several genomic features such as the presence of genes necessary for starch hydrolysis, and the lack of genes for hydrolysis of gelatin, 


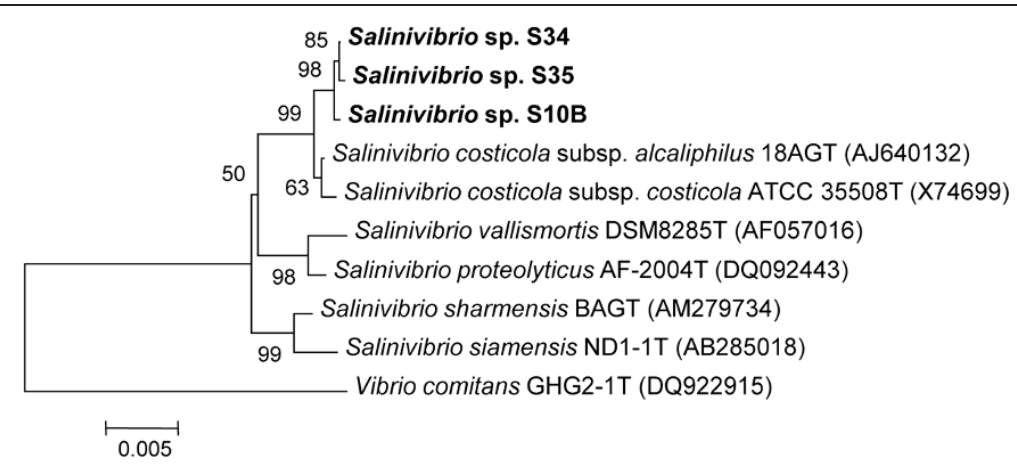

Figure 3 Phylogenetic tree based on 16S rRNA gene sequences (ca. 1561 bp) using the neighbor-joining method. The optimal tree with the sum of branch length $=0.11633261$ is shown. Bootstrap test (1000 replicates) is shown next to the branches. The tree is drawn to scale, with branch lengths in the same units as those of the evolutionary distances used to infer the phylogenetic tree. The evolutionary distances analysis involved 10 nucleotide sequences. All positions with less than 95\% site coverage were eliminated. That is fewer than 5\% alignment gaps, missing data, and ambiguous bases were allowed at any position. There were a total of 1365 positions in the final dataset. Vibrio comitans was used as outgroup.

nitrate reduction and tyrosine decomposition, characteristics found in $S$. costicola subsp. alcaliphilus, type strain $18 \mathrm{AG}^{\mathrm{T}}[29]$.

\section{Resistance to $\mathrm{NaCl}$, arsenic and UV-B radiation}

The novel Salinivibrio strains showed similar phenotypic characteristics concerning their resistance to extreme conditions (Figure 4A-D). Salt tolerance was lower in the three novel Salinivibrio strains than in the S. costicola subsp. alcaliphilus and S. costicola subsp. costicola. These subspecies tolerate up to $25 \% \mathrm{NaCl}$ [29]. The three novel strains grew on plates up to $15 \%$ of $\mathrm{NaCl}$, but not in the absence of this salt (Figure 4B). Under an intensity of $1.3 \mathrm{~W} / \mathrm{m}^{2}$, the strains resisted to UV-B radiations as high as $19 \mathrm{KJ} / \mathrm{m}^{2}$ (corresponding to $240 \mathrm{~min}$. of exposure). Unexpectedly, the assay showed a growth recovery in 120 minutes, suggesting physiologic response through DNA damage inducible SOS system (Figure 4A). The three novel strains were able to grow in $200 \mathrm{mM}$ of arsenate (Figure $4 \mathrm{C}$ ) and $2.5 \mathrm{mM}$ arsenite (the lowest concentration evaluated) (Figure 4D).

The draft genomes of three novel strains contain genes with a potential role in DNA repair. We found the complete set of genes for RecBCD helicase/nuclease and UvrABC endonuclease holoenzymes, respectively involved in the recombinational repair of double strand which breaks in DNA and "short-patch" of genetic mutations by excision and replacement of aberrant nucleotides. Homo$\operatorname{logs}$ for $\operatorname{rec} A$ and $\operatorname{rec} X$ genes were also detected in the genomes of strains S34 and S35. The ssDNA binding protein RecA acts centrally in SOS response (i.e. Rec repair system) and other homologous-recombination-based DNA repair, initiating the exchange of strands between two recombining DNA molecules. RecX modulates RecA activity by direct protein-protein interaction, blocking the extension of RecA filaments to avoid aberrant DNA transactions
[30,31]. DNA damage in Salinivibrio strains may result in from ionizing radiation, oxidative damage, and a range of other factors [32,33].

In addition, the novel Salinivibrio strains contained gene homologs of deoxyribodipyrimidine photolyase, and one gene coding for a transcriptional regulator of the Mer family, associated with photolyases. Deoxyribodipyrimidine photolyases catalyze the light-dependent monomerization $(300-600 \mathrm{~nm})$ of cyclobutyl pyrimidine dimers, which are formed between adjacent bases on the same DNA strand upon exposure to UV radiation [34-36]. These proteins have no significant similarity to Salinivibrio costicola subsp. costicola ATCC33508. The existence and the efficiency of these proteins in HAAL were already reported in strains of the genus Acinetobacter [37]. The UV-B resistance observed for the isolated Salinivibrio strains (Figure 4A) was lower than the one observed for Acinetobacter isolates from HAAL, but higher than the one observed for spore forming bacteria isolated from high altitudes air [38], reinforcing the ecologic versatility of these Salinivibrio strains.

One of the most impressive features of the Socompa Lake is the high arsenic content in the water [1], which is around the concentration of such metalloid encountered in the Mono Soda Lake, California $\left(200 \mathrm{MM} \mathrm{HAsO}_{4}{ }^{2-}\right.$, approximately $19.8 \mathrm{mg} / \mathrm{Lt} \mathrm{As}^{0}$ ) [39]. In general, these concentrations are lethal for a variety of microbes, but some specialized bacteria have evolved mechanisms of resistance to toxic levels of arsenic, which, in most cases, are based on the production of oxidoreductases that act on the prevailing inorganic arsenic oxidative states, $5+$ (arsenates) and $3+$ (arsenites) [40]. The three novel salinivibrios were slightly less resistant to arsenic than Exiguobacterium from the same lake [41], but they grew on higher arsenic concentrations than the ones tested in GFAJ-1 strain from the Mono Lake [42,43]. 


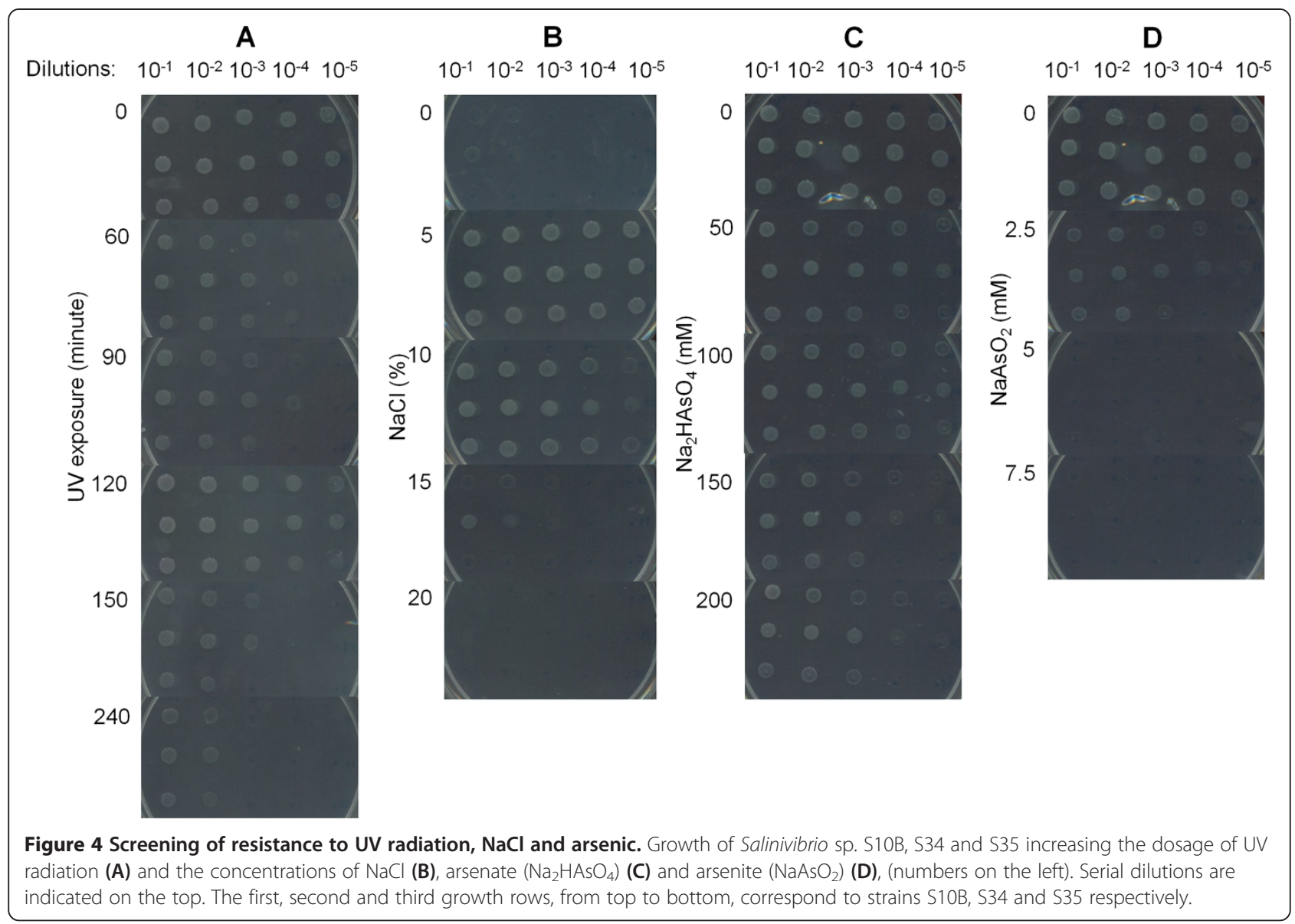

The three novel Salinivibrio strains presented homologs to the five genes composing the arsenate and arsenite resistance operon arsRDABC (Figure 5) firstly characterized in Escherichia coli plasmid R773 [44]. On the other hand, ars $D A C$ genes were not detected in the genomic contents of the S. costicola ATCC33508 strain. In this detoxification system the cytoplasmic oxidoreductase ArsC reduces arsenate to arsenite in an ATP-glutathione-glutaredoxin dependent way, and the toxic arsenite is excreted by the ArsAB efflux pump [40]. ArsD is a metallochaperone that scavenges arsenite from the cytosol and transfers it to the ArsAB pump ATPase component, ArsA, increasing arsenite extrusion rate to confer resistance even when it is present at low and subtoxic concentrations [45]. ArsR is an operon trans-acting transcriptional regulator. In the strains S35 and S10B all genes arsDAC are disposed contiguously reinforcing the idea of an active operon, while in strain S34, the putative arsD is placed at a different genomic locus distant from ars $A C$ (Figure 5). The ars $D A C$ genes were not detected in the genome of $S$. costicola ATCC33508. The putative ArsA from S35 and S10B are highly similar (99\% identity, E-value 1e-03), 584 amino acid (aa) long proteins, containing two catalytic domains in tandem. These hypothetical proteins are also similar
(76\% similarity, E-value 1e-03) to the characterized ArsA ATPase from Escherichia coli, a 583 aa long protein that also contains two homologous domains (A1 and A2) connected by a flexible linker. Both E. coli ArsA domains bind and hydrolyze ATP when activated by arsenite or antimonite $\left(\mathrm{Sn}^{+3}\right)$, and the loss of either domain leads to the loss of the enzymatic activity [46]. On the other hand, ars $A$ from strain S34 codes for a one domain only shorter protein (259 aa) (Figure 5). The putative ArsA domain from S34 is identical to A2 domain from the ArsA of isolates S35 and S10B (data not shown). Additionally, the putative arsB from isolate $\mathrm{S} 34$ codes for a protein truncated at both the carboxi (27 aa shorter) and amino-termini (186 to 211 aa shorter than S35 and S10B ArsB protein respectively) portions. ArsC-dependent arsenate detoxification systems are ubiquitously found in bacteria [47]. Indeed, a putative additional and thioredoxin-dependent ArsC enzyme was also detected in the genomes of the three Salinivibrio strains and the type strain $S$. costicola, which lacks an ars$D A B C$-like operon. All three novel strains also presented from one to three copies of an $\operatorname{ars} B$ arsenite efflux pump. Finally, putative genes for the key molybdoproteins involved in arsenite oxidation coupled with to oxygen or nitrite (anaerobic) reduction (ArrAB), or arsenate reduction 
Salinivibrio sp. S35

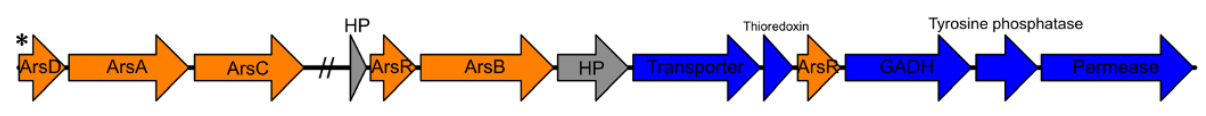

Salinivibrio sp. 534

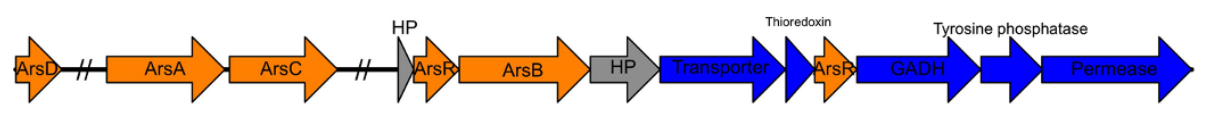

Salinivibrio sp. S10B

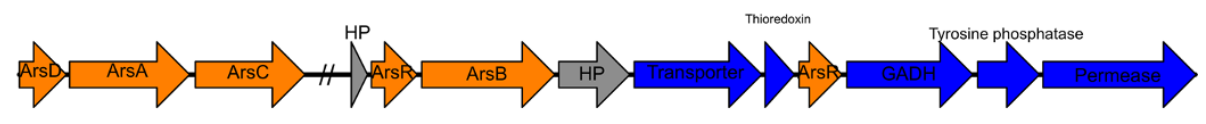

Salinivibrio costicola subsp. costicola ATCC33508

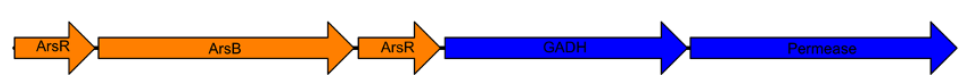

Figure 5 Schematic organization of putative genes involved (blue arrows) or related (orange arrows) to arsenate/arsenite resistance in Salinivibrio strains. The double slash represents genes placed at a different genomic locus. Arrows indicate the transcriptional orientation; the asterisk indicates that all genes are positioned in reverse strand. The gray arrows indicate hypothetical proteins. HP, hypothetical proteins; GADH, NAD-dependent glyceraldehyde-3-phosphate dehydrogenase (EC 1.2.1.12).

to arsenite in anaerobic respiratory process (AsoAB) were not detected in the genomes of the three novel Salinivibrio strains by automatic annotation or BLAST searches.

Another characteristic of the salinivibrios from Socompa Lake and the S. costicola subsp. costicola ATCC33508 is the absence of primary $\mathrm{Na}+$ pumps in their genomic contents, as seen in several other alkaliphiles and hyperthermophiles bacteria [48-52]. The analyzed Salinivibrio spp. only have secondary transporters, with Na symports being the principal. Glycine, Alanine, phosphate, glutamate, propionate and proline could be taken up by these cells by $\mathrm{Na}$ symport mechanism. The similarity between the three novel salinivibrios from Socompa and the ATCC33508 regarding $\mathrm{Na}$ transport may be due to Socompa Lake sodium concentrations of $2.8 \%$ are similar to the ones encountered in the sea, and therefore, there is no need for the novel salinivibrio strains to devote high energy and DNA content in order to have to have a sophisticated $\mathrm{Na}$ transport system. These results contradict the idea of primary sodium pumping as an adaptation to high external $\mathrm{pH}$ (8 in Socompa lake) [53].

\section{Genomic attributes related to osmoregulation}

We found several genes related to osmotic stress in the genomes of the salinivibrio strains. The primary response to high-osmolarity stress is the uptake of potassium $[54,55]$ and the genes for potassium uptake proteins TrkA and TrkH were present. The trk genes were dispersed in these genomes as in most bacteria studied thus far, with a few exceptions, like $V$. alginolyticus [56]. Moreover, it was reported that the $\operatorname{TrkH}$ system requires trkE, but here,
TrkAH appears to be independent from of TrkE similarly as seen for $V$. alginolyticus [56]. A secondary response to high environmental osmolarity is the replacement of the intracellular $\mathrm{K}^{+}$by compatible solutes [55]. The genes for a high-affinity choline uptake protein (bet T), the L-proline glycine betaine $\mathrm{ABC}$ transport system permease proteins (proW, proV, proX), the glycine betaine transporter (opuD) and glycerol uptake facilitator protein $(g l p F)$ are present in all three novel strains. Glycerol is prevalent as an osmolyte in eukaryotic organisms [57,58], but polar noncharged solutes have not been identified as an osmolyte in bacteria or archaea [59]. It is possible that the glycerol uptake is linked to the glycerolipid metabolism according to our Kegg metabolic analysis. Also, we found in the novel strains the genes for choline dehydrogenase (bet $A)$, and betaine aldehyde dehydrogenase (bet $B$ ) responsible for the biosynthesis of betaine and genes for the L-2,4diaminobutyric acid acetyltransferase $(e c t A)$, diaminobutyrate-pyruvate aminotransferase (ectB), aspartokinase (ask-ect) and L-ectoine synthase (ectC) responsible for the biosynthesis of ectoine, reinforcing the gene repertoire for the osmoregulation. Some bacteria (e.g. Actinopolyspora halophila, Halomonas elongata, and Escherichia coli) are able to synthesize betaine by the enzymes BetA and BetB from choline [51,59]. Ectoine is the major osmolyte in aerobic chemoheterotrophic bacteria [59]. It has also been found as the major solute in bacteria from the alkaline, hypersaline Mono Lake [60], and also could be present in salinivibrios [61]. The presence of this gene repertoire in the novel salinivibrios suggests that these strains might be applying different strategies, such as the uptake of $\mathrm{K}^{+}$and 
the biosynthesis of compatible solutes, to cope with the osmotic stress in Socompa Lake.

\section{Extremophilic hydrolytic enzymes and energy production} We found a diversity of genes coding for amylases, proteases, lipases and pullulanases in the genomes of the three novel strains that are related to enzymes that appear to function under broad ranges of salinity $(0-4 \mathrm{M})$ and $\mathrm{pH}$ (8.5-10) [62]. Ortholog genes for the alpha-amylase were present in all strains (except Salinivibrio sp. S10B) and had high identity to the alpha-amylase of the halolophilic Halomonas meridiana [63]. The proteases encoded in the genome of the sequenced strains presented $>75 \%$ aminoacid identity to the one from Salinivibrio proteolyticus with all orthologs belonging to the M4 family of metalloproteases. All proteins showed similarity $(>90 \%$, E-value 1e-03) to metalloproteases from $V$. corallyliticus. Since most of the zinc-metalloproteases that have been characterized so far are mainly active at neutral $\mathrm{pH}$ [64], we suggest that the genomes of the three novel Salinivibrio strains have evolved to adapt to the environmental conditions of the Socompa.

\section{Ferredoxins and flavodoxins}

We detected genes coding for ferredoxin $(\mathrm{Fd})$, ferredoxin $2 \mathrm{Fe}-2 \mathrm{~S}(\mathrm{Fd} 2)$ and ferredoxin $4 \mathrm{Fe}-4 \mathrm{~S}(\mathrm{Fd} 4)$. Ferredoxins are electron shuttles harboring iron-sulfur clusters that participate in oxido-reductive pathways in organisms displaying very different lifestyles. Ferredoxin levels decline under environmental stress and iron starvation, whereas flavodoxins, being isofunctional proteins, are induced under these conditions and replace ferredoxin in most reactions [65,66]. More specifically, Fd2 is involved in alanine biosynthesis, Fe-S cluster assembly and, cytochrome reduction [67]. Fd and Fd4 electron carriers are involved in the inorganic sulfur assimilation $[67,68]$. The former is not present in the type strain S. costicola subsp. costicola ATCC33508. The overrepresentation of ferredoxin genes for inorganic sulfur assimilation in the strains S10B, S34 and S35 suggests adaptation to the high concentrations of iron and sulfate contained in the Socompa Lake (1 and $31.8 \mathrm{mg} / \mathrm{L}$, respectively) [1]. We found genes encoding flavodoxin-1 and flavodoxin-2 in the genome of all strains studied in this work, which may allow survival and reproduction under changing environmental conditions.

\section{Retinal-protein encoding genes}

We identified proton-pumping rhodopsins encoding gene sequences in the genomes of three novel strains. Protonpumping rhodopsins are bacterial retinal-proteins that generate a proton gradient across the membrane, being utilized to drive an ATPase and thus providing energy from light [69]. Proton-pumping rhodopsins gene sequences from strains S10B (684 nt), S35 (684 nt) and S34 (807 nt) had $\geq 99 \%$ of identity (E-value $1 \mathrm{e}-0.3$, and 84 to $100 \%$ coverage) between them. We observed the presence of the genes coding for the geranylgeranyl pyrophosphate synthetase ( $c r t E)$, the phytoene dehydrogenase ( $c r t I)$, the phytoene synthase $(\mathrm{crtB})$, the putative lycopene cyclase (crtY) and a predicted Brp-like protein Blh, in the flanking region of the rhodopsin genes. The isopentenyl diphosphate delta-isomerase gene (idi) was presented, but located at distant from of the crt gene cluster. These enzymes are necessary for the $\beta$-carotene and the retinal biosynthesis from the geranylgeranyl pyrophosphate through phytoene and lycopene intermediates [70-72]. Brp and Blh are similar proteins that catalyze or regulate the conversion of $\beta$-carotene to retinal specifically [71]. Based on an alignment of isolates putative rhodopsins with xanthorhodopsin (XR) [GenBank:ABC44767], proteorhodopsin (PR) [GenBank:ADC84422], bacteriorhodopsin (BR) [GenBank:CAP14056], we identified 41 residues conserved among the six proteins (see Additional file 6: Figure S2). The three novel strains had hypothetical protein sequences with the majority of functionally important residues known to play roles in retinal binding, proton transport and structural folding such as Tyr-57 $7_{97}$, Arg-82 $2_{127}$, Asp-85 ${ }_{130}$, Trp-86 131 , Trp-182 236, Tyr- $185_{239}$, Asp-212 272 , Lys-216 276 and Asp-96 ${ }_{141}$ in the sequence of the homologous bacteriorhodopsin (the position in the current alignment is indicated by down-scribed numbers) [73-76]. In the case of the sequences from S10B and S35, although, a threonine replaces Asp- $212_{272}$, a residue involved in the proton releasing from the Schiff base to the external medium [74]. Furthermore, the lysine residue binding the retinal chromophore (Lys-216 276 ) is not present, and the last helicoidal segment, the helix G, is missing $[74,77,78]$, suggesting that the sequences from these two strains [GenBank:KC858135, KC858137] may represent new or not functional retinal proteins. Because of the relatively high genome sequencing coverage we do not expect this fact to be due to sequencing errors $[79,80]$. We also found that the residue Glu-194 248 , important for proton transport, is missing in the retinal protein sequences of S34, S10B and S35. However, Rammelsberg et. al. reported that none of the residues involved are completely indispensable for the functioning of the proton pump [78].

The retinal protein coding genes from the three novel salinivibrios were related to the XR gene from Salinibacter ruber (Additional file 6: Figure S2) [73]. The retinal protein from S34 had 45\% identity to XR (E-value $1 \mathrm{e}^{-66}$, and 91\% coverage). As in PR and XR, the internal proton donor homologous to Asp-96 $6_{141}$ is Glu [73,74]. Seven transmembrane alpha helices were detected by Phobius tool [81], conserved aa residues above mentioned [76] and a $\mathrm{Leu}_{138}$ residue corresponding to the PR position 105 
strongly suggested that putative protein XR [GenBank: KC858136] from S34 encodes a retinal-binding ion transporter protein that can create a proton gradient for ATP production and is spectrally tuned to green light [82]. This characteristic is in accordance with the source of the isolated strains from shallow sites of the Socompa Lake.

On the other hand, the carotene ketolase gene ( $c r t O$ or crtW) important for salinixantin and echinenone biosynthesis, both carotenoids light-harvesting antenna of XR are not present. Furthermore, the amino acids involved with salinixantin binding in Salinibacter xanthorhodopsin are replaced as follows: Leu $148_{182} / \mathrm{Val}$, Gly156 $190 / \mathrm{Trp}$, Phe-157 $191 /$ Val, Thr160 ${ }_{194} /$ Met, Asn191 $227 /$ Ile, Leu197 $233 /$ Ile, Gly $201_{237} /$ Leu, Met208 $244 /$ Leu and Met $211_{247} /$ Leu [73,83-87]. In fact, no carotenoids were isolated to explain the pink color of the strains. Nonetheless, they are not necessary for a functional XR [88]. These characteristics, the organization of the corresponding gene clusters and the Neighbor Joining based phylogenetic reconstruction (Figure 6) confirmed that the rhodopsins of salinivibrios are the most distant part of the XR group called supgroup II by Vollmers et al. [88]. The XRs most closely related to salinivibrios rhodopsins were the ones from Marinobacter and Spiribacter. The tree topology also showed that the Exiguobacterium sp. S17 PR is only distantly related to the three novel salinivibrio strains, corroborating the idea that there is no relationship between the habitat and the rhodopsin type, contradicting proposed by Vollmers et al. [88].

Moreover, the existence of proton-pumping rhodopsins in HAAL was already reported, but those sequences were more related to PRs from freshwater and marine environments [91]. In the present study we disclosed, for the first time, xanthorhodopsins-like genes in HAAL and the unusual occurrence of such genes in Salinivibrio. The presence of XR genes in the genomes of the three novel strains is an uncommon feature in salinivibrios that could possibly reflect the acquisition of these genes by horizontal gene transfer [92-95]. These genes could improve the ecological fitness of the three novel Salinivibrio strains that live in the Socompa Lake.

\section{Conclusions}

The phenotypic and genotypic plasticity observed in the three novel strains from Socompa Lake reflect their ability to adapt to changing environmental conditions. We disclose possible examples of horizontal gene transfer events, such as the unique phage genes in the stromatolite strain S10B, and reveal highly diverse DNA photolyases homologs, indicating possible examples of gene duplication.

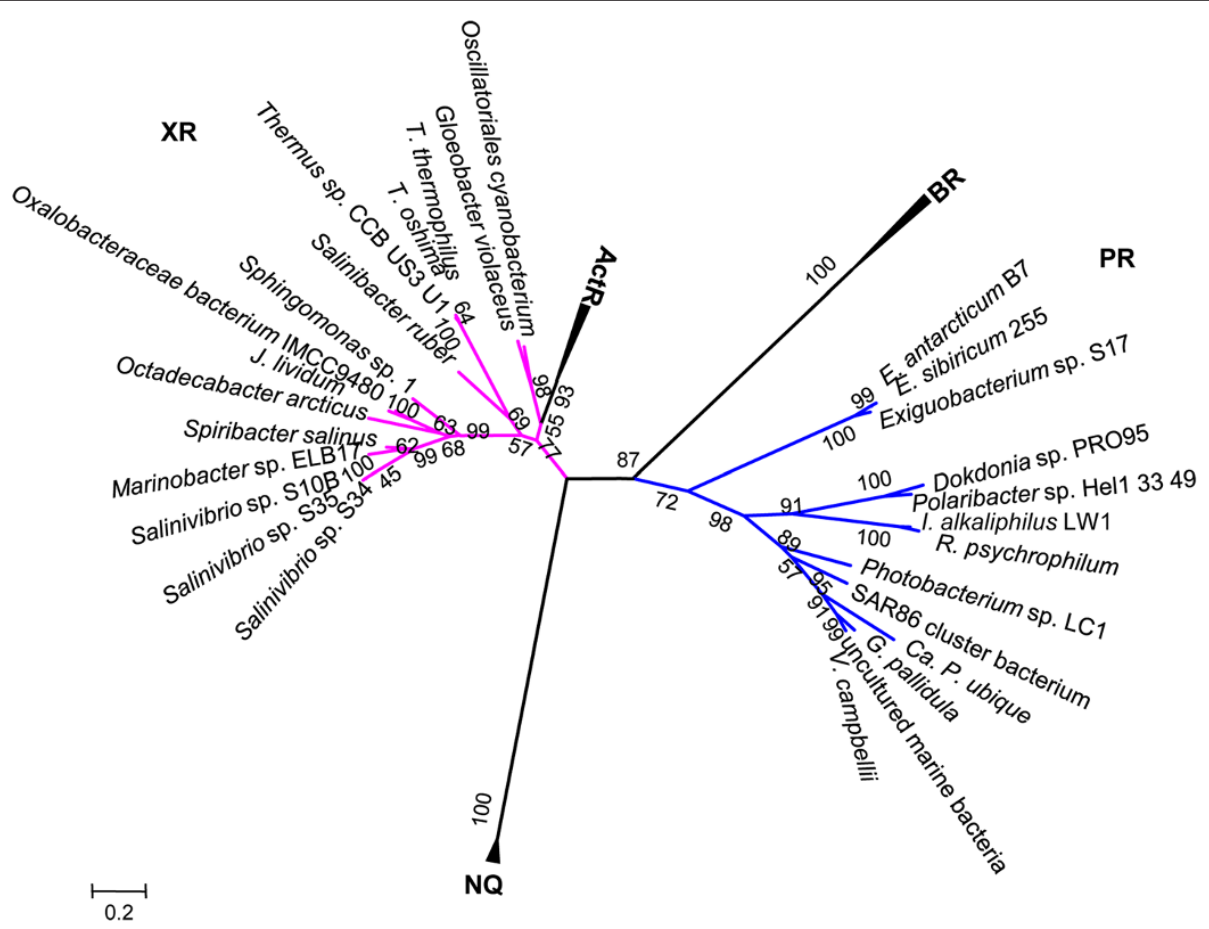

Figure 6 Phylogenetic relationships among microbial rhodopsins. The evolutionary history was inferred using the Neighbor-Joining method [89]. The optimal tree with the sum of branch length $=12.05461219$ is shown. The tree is drawn to scale, with branch lengths in the same units as those of the evolutionary distances used to infer the phylogenetic tree. The evolutionary distances were computed using the JTT matrix-based method [90] and are in the units of the number of amino acid differences per site. The rate variation among sites was modeled with a gamma distribution (shape parameter $=2.4$ ). The analysis involved 38 amino acid sequences. All positions containing gaps and missing data were eliminated. PR, proteorhodopsin (blue); XR, xanthorhodopsin (pink); NQ, NQ rhodopsin; BR, bacteriorhodopsin; ActR, actinorhodopsin. 
The novel salinivibrio strains appear to have evolved cellular mechanisms for energy production from light using rhodopsins possibly recruited from other types of bacteria. The phenotypic tests and the presence of genes related to arsenic resistance, DNA repair, and osmoregulation reflect the ability of the novel strains to thrive in harsh environmental conditions. The high genomic similarity observed among the three novel salinivibrios also reflects the ample spatial distribution of this new taxon in different habitats (sediments, stromatolite, and water) of the Socompa Lake. However, the high number of unique genes found in each of the salinivibrios, also suggests that each of the three novel strains represents different co-occurring populations within a new species, rather than a single clonal organism occurring in different habitats of the Socompa Lake. These niche-related genomic signatures are represented by genes such as the ones involved in cobalamine biosynthesis of S35 (water), and for capsular polysaccharide synthesizing enzyme in S34 (sediment), giving these strains properties to develop different roles in their respective habitat.

\section{Methods}

Isolation and growth of the strains

Salinivibrio sp. S10B, S34 and S35 strains were isolated from stromatolite, sediment and water of Socompa Lake (S 243' $34^{\prime \prime} \mathrm{W} 68^{\circ} 12^{\prime} 42^{\prime \prime}$ ) respectively, during February 2011 (Figure 1). The lake water at the sampling site was alkaline ( $\mathrm{pH} 8.5$ ), contained $18 \mathrm{mg} / \mathrm{Lt} \mathrm{As}{ }^{0}$ total, $114 \mathrm{mS} / \mathrm{cm}^{2}$ salinity and $2.8 \% \mathrm{Na}$. They were obtained by plating in situ aliquots of the source substrates onto MGM 10\% medium $\left(\mathrm{L}^{-1}\right)$ containing $333 \mathrm{~mL}$ salt water $30 \%(\mathrm{pH} 7.5), 5$ g tryptone, $1 \mathrm{~g}$ yeast extract. Salt water $30 \%(\mathrm{pH} 7.5)$ contains $240 \mathrm{~g} \mathrm{NaCl}, 30 \mathrm{~g} \mathrm{MgCl}_{2} \cdot 6 \mathrm{H}_{2} \mathrm{O}, 35 \mathrm{~g} \mathrm{MgSO}_{4} \cdot 7 \mathrm{H}_{2} \mathrm{O}, 7 \mathrm{~g}$ $\mathrm{KCl}, 5 \mathrm{~mL}$ of $1 \mathrm{M} \mathrm{CaCl}_{2} \cdot 2 \mathrm{H}_{2} \mathrm{O}$. Growth was carried out under aerobic conditions at $30^{\circ} \mathrm{C}$. Pure cultures were maintained in vials with $20 \%$ glycerol at $-80^{\circ} \mathrm{C}$. The accession numbers of the $16 \mathrm{~S}$ rRNA genes of S35, S34 and S10B strains are HF953987, FN994183, FR668583, respectively. All newly classified Salinivibrio strains were deposited at the World Data Centre for Microorganism (WDCM) Banco Nacional de Microorganismos Argentina http://inba.agro.uba.ar/ (ID number; BNM 535 for Salinivibrio sp. S35, BNM 536 for Salinivibrio sp. S34, and BNM 537 for Salinivibrio sp. S10B).

\section{Ion torrent-based genome sequencing}

The genomic DNA of Salinivibrio spp. S10B, S34 and S35 was extracted using the method of Pitcher et al. [96]. The Ion Torrent sequencing was performed as described by Quail et al. [79] with minor modifications as described here. Library preparation was carried out using the Ion Plus Fragment Library kit, with $1 \mu \mathrm{g}$ of DNA diluted in $50 \mu$ l of Low Tris-EDTA buffer. The
DNA was fragmented by using the BioRuptor ${ }^{\bullet}$ sonication system as described in Ion Plus Fragment Library Kit protocol. End repair, adapter ligation, nick repair and amplification (8 cycles) were also performed as described in the Ion Plus Fragment Library protocol. Size selection after adapter ligation was performed using 2\% agarose gel, with collection between $300 \mathrm{bp}$ and $400 \mathrm{bp}$. The quality and the concentration of the libraries were determined by means of the Agilent 2100 Bioanalyzer (Agilent Technologies) and the associated High Sensitivity DNA kit (Agilent Technologies), and by the Applied Biosystems ${ }^{\oplus}$ 7500 Real-Time PCR system with Ion library Quantization kit using TaqMan`. The amount of library required for template preparation was calculated using the template dilution factor calculation described in the protocol. Emulsion PCR and enrichment steps were carried out in the Ion OneTouch $^{\text {Tx }} 200$ Template Kit v2. The Ion sphere particle quality assessment was carried out as outlined in this protocol. Ion torrent sequencing was undertaken using 314 chips. The Ion PGM $^{\mathrm{TM}} 200$ Sequencing kit was used for all sequencing reactions, following the recommended protocol. The Torrent suite 1.5 was used for preliminary analyses. The reads obtained were assembled using de novo Assembly in the Ion Torrent Platform based on the MIRA software [97]. The novel genomes were annotated automatically using The RAST server (Rapid Annotations Using Subsystems Technology) [98]. S. costicola subsp. costicola ATCC33508 was re-annotated for comparison. The novel strains were compared with S. costicola subsp. costicola ATCC33508 by pairwise reciprocal blastp analysis in RAST server.

\section{Genomic taxonomy analysis}

The genomic taxonomy analysis was performed according to Thompson et al. [99]. Similarity matrices and phylogenetic trees based on 16S rRNA gene sequences and Multilocus Sequence Analysis (MLSA) were constructed in the MEGA5 [100], using the Neighbor-Joining method [89]. The percentage of replicate trees in which the associated taxa clustered together was calculated based on bootstrap test after 1000 replicates [101]. The evolutionary distances were computed using the Maximum Composite Likelihood method and p-distance method for $16 \mathrm{~S}$ and MLSA respectively [102] and were represented as units of the number of base substitutions per site. The average Amino Acid identity (AAI) was calculated as described by Thompson et al. [99]. The genomic signature was determined by the dinucleotide relative abundance value for each genome according to Karlin et al. [103,104]. The genome distance was calculated using the Genome-To-Genome Distance Calculator (GGDC) [http://www.ggdc.dsmz.de] [105]. Distances between pairs of genomes by whole-genome pairwise sequence comparisons were determined using BLAST. 


\section{Phylogenetic analysis of xanthorhodopsin}

Phylogenetic groups were determined using exemplary representatives of each class of actinorhodopsins (ActRs), BRs, PRs, and NQ-rhodopsins from GenBank databases. Rhodopsins of Salinivibrio spp. S10B, S34, S35 and 12 XR-type rhodopsins were included in the analysis, Spiribacter salinus M19-40, Marinobacter sp. ELB17, Janthinobacterium lividum, Oxalobacteraceae bacterium IMCC9480, Octadecabacter arcticus 238, Thermus sp. CCB_US3_UF1, Thermus thermophilus JL-18, Thermus oshimai JL-2, Sphingomonas sp. ATCC31555, Gloeobacter violaceus, Oscillatoriales cyanobacterium JSC-12, Salinibacter ruber DSM13855. [GenBank:WP_016353389.1,WP_007350588.1,WP_010 401582.1 WP_009665646.1,YP_007702112.1,YP_00565 4147.1,YP_006059019.1,YP_006972578.1,WP_019370319. 1,WP_011140202.1,WP_009553991.1,ABC44767]. PR sequence of Exigubacterium sp. S17 from Socompa Lake also was used [Genbank: WP_016509804.1]. A multiple sequence alignment was obtained using the CLUSTAL-W algorithm [106]. To construct phylogenetic trees, we used the MEGA5 with 197 conserved amino acid positions [100] with maximum parsimony (MP) and neighbor-joining (NJ), and maximum likelihood (ML) methods. Phylogenetic trees were constructed by the NJ method based on the JTT model, followed by a 1,000replicate bootstrap analysis for statistical support to determine the appropriate model of amino acid replacement.

\section{Phenotypic analysis of resistance to $\mathrm{NaCl}$, arsenic and UV-B radiation}

Bacterial cultures were grown for $12 \mathrm{~h}$ and subjected to five serial dilutions. Aliquots of $10 \mu \mathrm{l}$ from each dilution were plated onto MGM 10\% agar plates, supplemented with $\mathrm{NaCl}, \mathrm{Na}_{2} \mathrm{HAsO}_{4} \cdot 7 \mathrm{H}_{2} \mathrm{O}$ or $\mathrm{NaAsO}_{2}$. For the $\mathrm{NaCl}$ assay, the salt water of MGM was prepared without this particular salt. For the arsenic assay the salt water was prepared with some changes; $300 \mathrm{~g} \mathrm{NaCl}, 0.83 \mathrm{~g} \mathrm{MgCl}_{2} \cdot 6 \mathrm{H}_{2} \mathrm{O}$ and $0.83 \mathrm{~g} \mathrm{MgSO}_{4} \cdot 7 \mathrm{H}_{2} \mathrm{O}\left(\mathrm{L}^{-1}\right)$. Controls were plated onto MGM $10 \%$ or without arsenic addition.

All assays were carried out in quadruplicate and incubated at $30^{\circ} \mathrm{C}$. In the UV radiation assay, the plates were exposed to for different time intervals using two 09815-06 lamps (Cole Parmer Instrument Company, with major emission line at $312 \mathrm{~nm}$ ), and dark controls were covered with an aluminum sheet. After 240 minutes all plates including dark control were incubated at $30^{\circ} \mathrm{C}$. Light intensity was measured using 09811-56 radiometer (Cole Parmer Instrument Company) at $312 \mathrm{~nm}$ and the plates were covered with an acetate sheet to block UV-C. For each phenotypic assay, the growth of each strain was compared to control conditions.

\section{Nucleotide sequence accession numbers}

The draft genomes of Salinivibrio spp. S34, S35, S10B (Whole Genome Shotgun) have been deposited at DDBJ/
EMBL/GenBank under the accession APMS00000000, AQOD00000000, AQOE00000000, respectively.

\section{Availability of supporting data}

The data set supporting the results (Figures 3, 6 and Additional file 5: Figure S1) of this article is available in the Treebase repository [http://purl.org/phylo/treebase/ phylows/study/TB2:S15865].

\section{Additional files} Additional file 1: Table S1. Features of the genomes of Salinivibrio strains
S34, S35, S10B and Salinivibrio costicola subsp. costicola ATCC33508.

Additional file 2: Table S2. Unique genes of Salinivibrio sp. S34 compared to the other salinivibrios (S35, S10B, ATCC33508). Strain isolated from sediment.

Additional file 3: Table S3. Unique genes of Salinivibrio sp. S35 compared to the other salinivibrios (S34, S10B, ATCC33508). Strain isolated from the water.

Additional file 4: Table S4. Unique genes of Salinivibrio sp. S10B compared to the other salinivibrios (S34, S35, ATCC33508). Strain isolated from stromatolite.

Additional file 5: Figure S1. Phylogenetic tree based on MLSA of eight housekeeping genes (ie. fts $Z, r p o A, r e c A$, top $A$, gap $A, m r e B, g y r B$ and $p y r H$ ) (ca. 10,234 bp) using the neighbor-joining method. The optimal tree with the sum of branch length $=0.47649594$ is shown. Bootstrap test after 1000 replicates are shown next to the branches. All positions containing gaps and missing data were eliminated. There were a total of 7395 positions in the final dataset.

Additional file 6: Figure S2. Multiple alignment of retinal protein amino acid sequences. Sequences of Salinivibrio (S34, S35 and S10B) and representative sequences from xantorhodopsin (XR) [GeneBank: ABC44767], proteorhodopsin (PR) [GeneBank:ADC84422] and bacteriorhodopsin (BR) [GeneBank:CAP14056]. Gray indicates amino acid in common between the 6 sequences. Transmembrane helices are underlined. Numbers in the top indicate the position of amino acid in the current alignment.

Competing interests

The authors declare that they have no competing interests.

\section{Authors' contributions}

MG and GMD performed the research and wrote the paper. MG performed physiological experiments and data analysis, GMD performed the annotation and the comparative analysis of genomes, MMAM sequencing the genomes; BSS helped in the data analysis; AET-S, LAC and GBG analytic tools and helped to modify the manuscript; MEF, CCT, FLT obtained funding for the original project idea. All authors read and approved this manuscript.

\section{Acknowledgements}

This study was supported in part by the Argentinean National Council for Science and Technology (CONICET), the Argentinean National Fund for Science and Technology (FONCyT; project PICT number 1221), CNPq, CAPES, and FAPERJ. AET-S was financially supported by FAPESP (2009/11612-1). The authors wish to acknowledge Dr. Wolfgang Gärtner for the generous critical reading of the manuscript.

\section{Author details}

'Laboratorio de Investigaciones Microbiológicas de Lagunas Andinas (LIMLA), Planta Piloto de Procesos Industriales Microbiológicos (PROIMI), CCT, CONICET, San Miguel de Tucumán, Tucumán, Argentina. Laboratório de Microbiologia, Instituto de Biologia, Universidade Federal do Rio de Janeiro (UFRJ), Rio de Janeiro, Brasil. ${ }^{3}$ Núcleo de Biotecnologia Ambiental, Mestrado Profissional em Tecnologias Aplicáveis a Bioenergia, Faculdade de Tecnologia e Ciências (FTC), Salvador, Brasil. ${ }^{4}$ SAGE-COPPE, CT2 Rua Moniz de Aragão, 
no.360 - Bloco 2, Rio de Janeiro, Brasil. ${ }^{5} \mathrm{Av}$. Carlos Chagas Fo. S/N - CCS IB -Laboratório de Microbiologia - Bloco A (Anexo) A3 - sl 102 - Cidade Universitária, Rio de Janeiro, RJ, Brasil.

Received: 31 December 2013 Accepted: 6 June 2014

Published: 13 June 2014

\section{References}

1. Farias ME, Rascovan N, Toneatti DM, Albarracin VH, Flores MR, Poire DG, Collavino MM, Aguilar OM, Vazquez MP, Polerecky L: The discovery of stromatolites developing at $3570 \mathrm{~m}$ above sea level in a high-altitude volcanic lake Socompa, Argentinean Andes. PLos One 2013, 8(1):e53497.

2. Allwood AC, Walter MR, Kamber BS, Marshall CP, Burch IW: Stromatolite reef from the early Archaean era of Australia. Nature 2006, 441(7094):714-718.

3. Burne RV, Moore LS: Microbialites; organosedimentary deposits of benthic microbial communities. Palaios 1987, 2:241-254

4. Schopf JW: Fossil evidence of Archaean life. Philos Trans R Soc B: Biol SCi 2006, 361(1470):869-885.

5. Riding R: The nature of stromatolites: 3,500 million years of history and a century of research. In Advances in Stromatolite Geobiology, Volume 131. Edited by Reitner J, Queric N-V, Gernot A. Berlin Heidelberg: Springer; 2011:29-74.

6. Hoffman P: Chapter 6.1 Stromatolite morphogenesis in Shark Bay, Western Australia, Volume 20. Amsterdam: Elsevier; 1976.

7. Jones B, Renaut RW, Konhauser KO: Genesis of large siliceous stromatolites at Frying Pan Lake, Waimangu geothermal field, North Island, New Zealand. Sedimentology 2005, 52:1229-1252.

8. Pedley M: Ambient temperature freshwater microbial tufas. Heidelberg: Springer; 2000

9. Play ford PE, Cockbain AE: Modern Algal Stromatolites at Hamelin Pool, A Hypersaline Barred Basin in Shark Bay, Western Australia. In Developments in Sedimentology, Volume Volume 20. Edited by Walter MR. Amsterdam: Elsevier; 1976:389-411.

10. Souza V, Espinosa-Asuar L, Escalante AE, Eguiarte LE, Farmer J, Forney L, Lloret L, Rodriguez-Martinez JM, Soberon X, Dirzo R, Elser JJ: An endangered oasis of aquatic microbial biodiversity in the Chihuahuan desert. Proc Natl Acad Sci U S A 2006, 103(17):6565-6570.

11. Takashima C, Kano A: Microbial processes forming daily lamination in a stromatolitic travertine. Sedimentary Geology 2008, 208(3-4):114-119.

12. Walter MR, Bauld J, Brock TD: Siliceous algal and bacterial stromatolites in hot spring and geyser effluents of yellowstone national park. Science 1972, 178(4059):402-405.

13. Smith FE: An investigation of a tait in rib bones of bacon. The determination of halophilic vibrio (n.ssp). Proc R Soc Queensland 1938, 49:29-52.

14. Mellado E, Moore ERB, Nieto JJ, Ventosa A: Analysis of $16 \mathrm{~S}$ rRNA gene sequences of Vibrio costicola strains: description of Salinivibrio costicola gen. Nov., comb. nov. Int I Syst Bacteriol 1996, 46:817-821.

15. Amoozegar MA, Schumann P, Hajighasemi M, Fatemi AZ, Karbalaei-Heidari HR HR: Salinivibrio proteolyticus sp. nov., a moderately halophilic and proteolytic species from a hypersaline lake in Iran. Int I Syst Evol Microbiol 2008, 58(Pt 5):1159-1163.

16. Chamroensaksri N, Tanasupawat S, Akaracharanya A, Visessanguan W, Kudo $\mathrm{T}$, Itoh T: Salinivibrio siamensis sp. nov., from fermented fish (pla-ra) in Thailand. Int J Syst Evol Microbiol 2009, 59(Pt 4):880-885.

17. Romano I, Orlando P, Gambacorta A, Nicolaus B, Dipasquale L, Pascual J, Giordano A, Lama L: Salinivibrio sharmensis sp. nov., a nove haloalkaliphilic bacterium from a saline lake in Ras Mohammed Park (Egypt). Extremophiles 2011, 15(2):213-220.

18. Garcia MT, Ventosa A, Ruiz-Barraquero F, Kocur M: Taxonomic study and amended description of Vibrio costicola. Int I System Bacteriol 1987, 37:251-256.

19. Huang CY, Garcia JL, Patel BK, Cayol JL, Baresi L, Mah RA: Salinivibrio costicola subsp. vallismortis subsp. nov., a halotolerant facultative anaerobe from Death Valley, and emended description of Salinivibrio costicola. Int I Syst Evol Microbiol 2000, 50 Pt 2:615-622.

20. Oren A: Diversity of halophilic microorganisms: environments, phylogeny, physiology, and applications. J Ind Microbiol Biotechnol 2002, 28(1):56-63.

21. Oren A: Halophilic Microorganisms and their Environments. In Cellular Origin and Life in Extreme Habitats, Volume 5. Edited by Seckbach J. London: Kluwer Academic Press; 2002
22. Ellwood DC, Keevil CW, Marsh PD, Brown CM, Wardell JN: Surface-associated growth. Phil Trans R Soc B 1982, 297(1088):517-532.

23. Eboigbodin $\mathrm{KE}$, Ojeda JJ, Biggs CA: Investigating the surface properties of escherichia coli under glucose controlled conditions and its effect on aggregation. Langmuir 2007, 23(12):6691-6697.

24. Thompson JR, Randa MA, Marcelino LA, Tomita-Mitchell A, Lim E, Polz MF: Diversity and dynamics of a north atlantic coastal Vibrio community. Appl Environ Microbiol 2004, 70(7):4103-4110.

25. Makarova KS, Haft DH, Barrangou R, Brouns SJJ, Charpentier E, Horvath P, Moineau S, Mojica FJM, Wolf YI, Yakunin AF, Van der Oost J, Koonin EV: Evolution and classification of the CRISPR-Cas systems. Nat Rev Micro 2011, 9(6):467-477.

26. Almendros C, Mojica FJM, Díez-Villaseñor C, Guzmán NM, García-Martínez J: CRISPR-Cas functional module exchange in escherichia coli. mBio 2014, 5(1):e00767-13.

27. Haines KC, Guillard RRL: Growth of vitamin B12-requiring marine diatoms in mixed laboratory cultures with vitamin B12-producing marine bacteria. J Phycol 1974, 10(3):245-252.

28. Thompson C, Chimetto L, Edwards R, Swings J, Stackebrandt E, Thompson F: Microbial genomic taxonomy. BMC Genomics 2013, 14(1):913.

29. Romano I, Gambacorta A, Lama L, Nicolaus B, Giordano A: Salinivibrio costicola subsp. alcaliphilus subsp. nov., a haloalkaliphilic aerobe from Campania Region (Italy). Syst App/ Microbiol 2005, 28(1):34-42.

30. Drees JC, Lusetti SL, Cox MM: Inhibition of RecA Protein by the Escherichia coli RecX Protein: modulation by the RecA C terminus and filament functional state. J Biol Chem 2004, 279(51):52991-52997.

31. Cox MM: The RecA protein as a recombinational repair system. $\mathrm{Mol}$ Microbiol 1991, 5(6):1295-1299.

32. Smith GR: How RecBCD enzyme and Chi promote DNA break repair and recombination: a molecular biologist's view. Microbiol Mol Biol Rev 2012, 76(2):217-228.

33. Wang J, Grossman L: Mutations in the helix-turn-helix motif of the Escherichia coli UvrA protein eliminate its specificity for UV-damaged DNA. J Biol Chem 1993, 268(7):5323-5331.

34. Sancar GB: Enzymatic photoreactivation: 50 years and counting. Mutat Res 2000, 451(1-2):25-37.

35. Sancar A: Structure and function of DNA photolyase and cryptochrome blue-light photoreceptors. Chem Rev 2003, 103(6):2203-2237.

36. Weber S: Light-driven enzymatic catalysis of DNA repair: a review of recent biophysical studies on photolyase. BBA-Bioenergetics 2005, 1707(1):1-23.

37. Albarracin VH, Pathak GP, Douki T, Cadet J, Borsarelli CD, Gartner W, Farias ME: Extremophilic Acinetobacter strains from high-altitude lakes in Argentinean Puna: remarkable UV-B resistance and efficient DNA damage repair. Orig Life Evol Biosph 2012, 42(2-3):201-221.

38. Shivaji S, Chaturvedi P, Begum Z, Pindi1 PK, Manorama R, Padmanaban DA, Shouche YS, Pawar S, Vaishampayan P, Dutt CBS, Datta GN, Manchanda RK, Rao UR, Bhargava PM, Narlikar JV: Janibacter hoylei sp. nov., Bacillus isronensis sp. nov. and Bacillus aryabhattai sp. nov., isolated from cryotubes used for collecting air from the upper atmosphere. Int I Syst Evol Microbiol 2009, 59(12):2977-2986.

39. Oremland RS, Stolz JF, Hollibaugh JT: The microbial arsenic cycle in Mono Lake. Calif FEMS Microbiol Ecol 2004, 48(1):15-27.

40. Silver S, Phung LT: Genes and enzymes involved in bacterial oxidation and reduction of inorganic arsenic. Appl Environ Microbiol 2005, 71(2):599-608.

41. Belfiore C, Ordonez OF, Farias ME: Proteomic approach of adaptive response to arsenic stress in Exiguobacterium sp. S17, an extremophile strain isolated from a high-altitude Andean Lake stromatolite. Extremophiles 2013, 17(3):421-431.

42. Erb TJ, Kiefer P, Hattendorf B, Gunther D, Vorholt JA: GFAJ-1 is an arsenateresistant, phosphate-dependent organism. Science 2012, 337(6093):467-470.

43. Reaves ML, Sinha S, Rabinowitz JD, Kruglyak L, Redfield RJ: Absence of detectable arsenate in DNA from arsenate-grown GFAJ-1 cells. Science 2012, 337(6093):470-473.

44. Chen CM, Misra TK, Silver S, Rosen BP: Nucleotide sequence of the structural genes for an anion pump. The plasmid-encoded arsenical resistance operon. J Biol Chem 1986, 261:15030-15038.

45. Yung-Feng Lin ARW, Rosen BP: An arsenic metallochaperone for an arsenic detoxification pump. Proc Natl Acad Sci U S A 2006, 103(42):15616-15622. 
46. Christopher Rensing MG, Rosen BP: Families of soft-metal-ion-transporting ATPases. J Bacteriol 2006, 181(19):5891-5897.

47. Mukhopadhyay R, Rosen BP, Phung LT, Silver S: Microbial arsenic: from geocycles to genes and enzymes. FEMS Microbiol Rev 2002, 26(3):311-325.

48. Deckert G, Wa PV, Gaasterland T, Young WG, Lenox AL, Graham DE, Overbeek R, Snead MA, Keller M, Aujay M, Huber R, Feldman RA, Short JM, Olsen GJ, Swanson RV: The complete genome of the hyperthermophilic bacterium Aquifex aeolicus. Nature 1998, 392:353-358.

49. Hideto Takami KN, Takaki Y, Maeno G, Sasaki R, Masui N, Fuji F, Hirama C, Nakamura Y, Ogasawara1 N, Kuhara2 S, Horikoshi K: Complete genome sequence of the alkaliphilic bacterium Bacillus halodurans and genomic sequence comparison with Bacillus subtilis. Nucleic Acid Res 2000, 28(21):4317-4331.

50. She Q, Sing RK, Confalonieri F, Zivanovic Y, Allard G, Awayez MJ, Chan-Weiher CC-Y, Clausen G, Curtis BA, De Moorse A, Erauso G, Fletcher C, Gordon PMK, Heikamp-de Jongg I, Jeffries AC, Kozera CJ, Medina N, Peng X, Thi-Ngoc HP Redder P, Schenk ME, Theriault C, Tolstrup N, Charlebois RL, Doolittle WF, Duguet M, Gaasterland T, Garretta RA, Ragan MA, Sensen CW, et al: The complete genome of the crenarchaeon Sulfolobus solfataricus P2. Proc Natl Acad Sci U S A 2001, 98(14):7835-7840.

51. Landfald B, Strom AR: Choline-glycine betaine pathway confers a high level of osmotic tolerance in Escherichia coli. J Bacteriol 1986, 165(3):849-855.

52. Falb M, P F, Palm P, Rodewald K, Hickmann V, Tittor J, Oesterhelt D: Living with two extremes: Conclusions from the genome sequence of Natronomonas pharaonis. Genome Res 2005, 15:1336-1343.

53. Sculachev VP: Membrane Bioenergetics. Berlin, New York: Springer-Verlag; 1988.

54. Epstein E, Rains DW: Carrier-mediated cation transport in barley roots: kinetic evidence for a spectrum of active sites. Proc Natl Acad Sci U S A 1965, 53(6):1320-1324.

55. Lucht JM, Bremer E: Adaptation of Escherichia coli to high osmolarity environments: osmoregulation of the high-affinity glycine betaine transport system proU. FEMS Microbiol Rev 1994, 14(1):3-20.

56. Nakamura T, Yamamuro N, Stumpe S, Unemoto T, Bakker EP: Cloning of the trkAH gene cluster and characterization of the Trk K(+)-uptake system of Vibrio alginolyticus. Microbiology 1998, 144(Pt 8):2281-2289.

57. Borowitzka $L$, Brown AD: The salt relations of marine and halophilic species of the unicellular green alga, Dunaliella. The role of glycerol as a compatible solute. Arch Mikrobiol 1974, 96(1):37-52.

58. Petrovic U, Gunde-Cimerman N, Plemenitas A: Cellular responses to environmental salinity in the halophilic black yeast Hortaea werneckii. Mol Microbiol 2002, 45(3):665-672.

59. Roberts MF: Organic compatible solutes of halotolerant and halophilic microorganisms. Saline Syst 2005, 1:5

60. Ciulla RA, Diaz MR, Taylor BF, Roberts MF: Organic osmolytes in aerobic bacteria from mono lake, an alkaline, moderately hypersaline environment. Appl Environ Microbiol 1997, 63(1):220-226.

61. Severin J, Wohlfarth A, Galinski EA: The predominant role of recently discovered tetrahydropyrimidines for the osmoadaptation of halophilic eubacteria. J Gen Microbiol 1992, 138(8):1629-1638.

62. Karbalaei-Heidari HR, Ziaee AA, Amoozegar MA, Cheburkin Y, Budisa N: Molecular cloning and sequence analysis of a novel zincmetalloprotease gene from the Salinivibrio sp. strain AF-2004 and its extracellular expression in E. coli. Gene 2008, 31(1-2):196-203.

63. Coronado MJ, Vargas C, Mellado E, Tegos G, Drainas C, Nieto JJ, Ventosa A: The alpha-amylase gene amyH of the moderate halophile Halomonas meridiana: cloning and molecular characterization. Microbiology 2000, 146(4):861-868.

64. Häse CC, Finkelstein RA: Bacterial extracellular zinc-containing metalloproteases. Microbiol Rev 1993, 57(4):823-837.

65. Lodeyro AF, Ceccoli RD, Pierella Karlusich JJ, Carrillo N: The importance of flavodoxin for environmental stress tolerance in photosynthetic microorganisms and transgenic plants. Mechanism, evolution and biotechnological potential. FEBS Lett 2012, 586(18):2917-2924.

66. Sancho J: Flavodoxins: sequence, folding, binding, function and beyond Cell Mol Life Sci 2006, 63(7-8):855-864.

67. Hase T, Schürmann P, Knaff D: The Interaction of Ferredoxin with Ferredoxin-Dependent Enzymes. In Photosystem I, Volume 24. Edited by Golbeck J. Netherlands: Springer; 2006:477-498.

68. van der Ploeg JR, Eichhorn E, Leisinger T: Sulfonate-sulfur metabolism and its regulation in Escherichia coli. Arch Microbiol 2001, 176(1-2):1-8.
69. Béja O, Aravind L, Koonin EV, Suzuki MT, Hadd A, Nguyen LP, Jovanovich SV, Gates CM, Feldman RA, Spudich JL, DeLong EF: Bacterial rhodopsin: evidence for a new type of phototrophy in the sea. Science 2000, 289:1902-1905.

70. Misawa N, Satomi Y, Kondo K, Yokoyama A, Kajiwara S, Saito T, Ohtani T, Miki W: Structure and functional analysis of a marine bacterial carotenoid biosynthesis gene cluster and astaxanthin biosynthetic pathway proposed at the gene level. J Bacteriol 1995, 177(22):6575-6584.

71. Peck RF, Echavarri-Erasun C, Johnson EA, Ng WV, Kennedy SP, Hood L, DasSarma S, Krebs MP: brp and blh are required for synthesis of the retinal cofactor of bacteriorhodopsin in Halobacterium salinarum. J Biol Chem 2001, 276(8):5739-5744.

72. Sabehi G, Loy A, Jung KH, Partha R, Spudich JL, Isaacson T, Hirschberg J, Wagner M, Beja O: New insights into metabolic properties of marine bacteria encoding proteorhodopsins. PLOS Biol 2005, 3(8):e273.

73. Balashov SP, Imasheva ES, Boichenko VA, Anton J, Wang JM, Lanyi JK: Xanthorhodopsin: a proton pump with a light-harvesting carotenoid antenna. Science 2005, 309(5743):2061-2064

74. Luecke $\mathrm{H}$, Richter HT, Lanyi JK: Proton transfer pathways in bacteriorhodopsin at 2.3 angstrom resolution. Science 1998, 280(5371):1934-1937.

75. Peralvarez-Marin A, Marquez M, Bourdelande JL, Querol E, Padros E: Thr-90 plays a vital role in the structure and function of bacteriorhodopsin. J Biol Chem 2004, 279(16):16403-16409.

76. Spudich $J$, Yang CS, Jung KH, Spudich EN: Retinylidene proteins: structures and functions from archaea to humans. Annu Rev Cell Dev Biol 2000, 16:365-392.

77. Lemke HD, Oesterhelt D: Lysine 216 is a binding site of the retinyl moiety in bacteriorhodopsin. FEBS Lett 1981, 128(2):255-260.

78. Rammelsberg R, Huhn G, Lubben M, Gerwert K: Bacteriorhodopsin's intramolecular proton-release pathway consists of a hydrogen-bonded network. Biochemistry 1998, 37(14):5001-5009.

79. Quail MA, Smith M, Coupland P, Otto TD, Harris SR, Connor TR, Bertoni A, Swerdlow HP, GU Y: A tale of three next generation sequencing platforms: comparison of Ion Torrent, Pacific Biosciences and Illumina MiSeq sequencers. BMC Genomics 2012, 13:341.

80. Rothberg JM, Hinz W, Rearick TM, Schultz J, Mileski W, Davey M, Leamon JH, Johnson K, Milgrew MJ, Edwards M, Hoon J, Simons JF, Marran D, Myers JW, Davidson JF, Branting A, Nobile JR, Puc BP, Light D, Clark TA, Huber M, Branciforte JT, Stoner IB, Cawley SE, Lyons M, Fu Y, Homer N, Sedova M, Miao X, Reed B: An integrated semiconductor device enabling non-optical genome sequencing. Nature 2011, 475(7356):348-352.

81. Goujon M, McWilliam H, Li W, Valentin F, Squizzato S, Paern J, Lopez R: A new bioinformatics analysis tools framework at EMBL-EBI. Nucleic Acids Res 2010, 38(suppl 2):W695-W699.

82. Man D, Wang W, Sabehi G, Aravind L, Post AF, Massana R, Spudich EN, Spudich $J L$, Beja O: Diversification and spectral tuning in marine proteorhodopsins. EMBO J 2003, 22(8):1725-1731.

83. Balashov SP, Imasheva ES, Choi AR, Jung KH, Liaaen-Jensen S, Lanyi JK Reconstitution of gloeobacter rhodopsin with echinenone: role of the 4-keto group. Biochemistry 2010, 49(45):9792-9799.

84. Imasheva ESBS, Choi AR, Jung KH, Lanyi JK: Reconstitution of Gloeobacter violaceus rhodopsin with a light-harvesting carotenoid antenna. Bichemistry 2009, 48:10948-10955.

85. Luecke H, Schobert B, Stagno J, Imasheva ES, Wang JM, Balashov SP, Lanyi JK: Crystallographic structure of xanthorhodopsin, the light-driven proton pump with a dual chromophore. Proc Natl Acad Sci U S A 2008, 105(43):16561-16565.

86. Makino T, Harada H, Ikenaga H, Matsuda S, Takaichi S, Shindo K, Sandmann G, Ogata T, Misawa N: Characterization of cyanobacterial carotenoid ketolase CrtW and hydroxylase CrtR by complementation analysis in Escherichia coli. Plant Cell Physiol 2008, 49(12):1867-1878.

87. Mongodin EF, Nelson K, Daugherty S, Deboy R, Wister J, Khouri H, Weidman J, Walsh D, Papke R, Perez GS: The genome of Salinibacter ruber: convergence and gene exchange among hyperhalophilic bacteria and archaea. Proc Natl Acad Sci U S A 2005, 102(50):18147-18152.

88. Vollmers J, Voget S, Dietrich S, Gollnow K, Smits M, Meyer K, Brinkhoff T, Simon M, Daniel R: Poles apart: arctic and antarctic octadecabacter strains share high genome plasticity and a new type of xanthorhodopsin. PLoS One 2013, 8(5):e63422. 
89. Saitou N, Nei M: The neighbor-joining method: a new method for reconstructing phylogenetic trees. Mol Biol Evol 1987, 4(4):406-425.

90. Jones DT, Taylor WR, Thornton JM: The rapid generation of mutation data matrices from protein sequences. Comp Appl Biosc 1992, 8(3):275-282.

91. Bohorquez LC, Ruiz-Perez CA, Zambrano MM: Proteorhodopsin-like genes present in thermoacidophilic high-mountain microbial communities. Appl Environ Microbiol 2012, 78(21):7813-7817.

92. Anton J, Oren A, Benlloch S, Rodriguez-Valera F, Amann R, Rossello-Mora R: Salinibacter ruber gen. nov., sp. nov., a novel, extremely halophilic member of the Bacteria from saltern crystallizer ponds. Int J Syst Evol Microbiol 2002, 52(Pt 2):485-491.

93. Fuhrman JA, Schwalbach MS, Stingl U: Proteorhodopsins: an array of physiological roles? Nat Rev Micro 2008, 6(6):488-494.

94. Kwon SK, Kim BK, Song JY, Kwak MJ, Lee CH, Yoon JH, Oh TK, Kim JF: Genomic makeup of the marine flavobacterium Nonlabens (Donghaeana) dokdonensis and identification of a novel class of rhodopsins. Genome Biol Evol 2013, 5(1):187-199.

95. Sharma AK, Spudich JL, Doolittle WF: Microbial rhodopsins: functional versatility and genetic mobility. Trends Microbiol 2006, 14(11):463-469.

96. Pitcher DG, Saunders NA, Owen RJ: Rapid extraction of bacterial genomic DNA with guanidium thiocyanate. Lett Appl Microbiol 1989, 8(4):151-156.

97. Chevreux BPT, Drescher B, Driesel AJ, Müller WEG, Wetter T, Suhai S: Using the miraEST assembler for reliable and automated mRNA transcript assembly and SNP Detection in sequenced ESTs. Genome Res 2004, 14:1147-1159

98. Aziz RK, Bartels D, Best AA, DeJongh M, Disz T, Edwards RA, Formsma K, Gerdes S, Glass EM, Kubal M, Meyer F, Olsen GJ, Olson R, Osterman AL, Overbeek RA, McNeil LK, Paarmann D, Paczian T, Parrello B, Pusch GD, Reich C, Stevens R, Vassieva O, Vonstein V, Wilke A, Zagnitko O: The RAST server: rapid annotations using subsystems technology. BMC Genomics 2008, 9:75.

99. Thompson CC, Vicente AC, Souza RC, Vasconcelos AT, Vesth T, Alves NJ, Ussery DW, lida T, Thompson FL: Genomic taxonomy of vibrios. BMC Evol Biol 2009, 9(258).

100. Tamura K, Peterson D, Peterson N, Stecher G, Nei M, Kumar S: MEGA5: molecular evolutionary genetics analysis using maximum likelihood, evolutionary distance, and maximum parsimony methods. Mol Biol Evol 2011, 28(10):2731-2739.

101. Felsenstein J: Confidence limits on phylogenies: an approach using the bootstrap. Evolution 1985, 39:783-791.

102. Tamura K, Nei M, Kumar S: Prospects for inferring very large phylogenies by using the neighbor-joining method. Proc Natl Acad Sci U S A 2004, 101(30):11030-11035.

103. Karlin S, Mrázek J, Campbell AM: Compositional biases of bacterial genomes and evolutionary implications. J Bacteriol 1997, 179(12):3899-3913.

104. Karlin S: Global dinucleotide signatures and analysis of genomic heterogeneity. Curr Opin Microbiol 1998, 1(5):598-610.

105. Auch AF, von Jan M, Klenk H-P, Göker M: Digital DNA-DNA hybridization for microbial species delineation by means of genome-to-genome sequence comparison. Stand Genomic Sci 2010, 2(1):117-134.

106. Larkin MA, Blackshields G, Brown NP, Chenna R, McGettigan PA, McWilliam $H$, Valentin F, Wallace IM, Wilm A, Lopez R, Thompson JD, Gibson TJ, Higgins DG: Clustal W and Clustal X version 2.0. Bioinformatics 2007, 23(21):2947-2948.

doi:10.1186/1471-2164-15-473

Cite this article as: Gorriti et al:: Genomic and phenotypic attributes of novel salinivibrios from stromatolites, sediment and water from a high altitude lake. BMC Genomics 2014 15:473.

\section{Submit your next manuscript to BioMed Central and take full advantage of:}

- Convenient online submission

- Thorough peer review

- No space constraints or color figure charges

- Immediate publication on acceptance

- Inclusion in PubMed, CAS, Scopus and Google Scholar

- Research which is freely available for redistribution

Submit your manuscript at www.biomedcentral.com/submit
C Biomed Central 